\title{
The bust, the boom and the sanctions in trade relations with Russia
}

\author{
Viljar Veebel \\ Baltic Defense College, Tartu, \\ Estonia \\ Viljar.veebel@ut.ee \\ Raul Markus \\ Tallinn University of Technology, Tallinn, \\ Estonia \\ raul@optium.ee
}

Abstract. Next to the growing tensions in global economic arena, the challenges for Estonia, Latvia and Lithuania are often related to Russia's actions and ambitions. Mutual economic relations have been particularly tense at the beginning of the 1990s, in 1995-1997 and then in 2007-2009, when Russia has imposed sanctions against the Baltic countries and has been putting economic, political or propagandist pressure on them. The current "sanctioning war" is seriously testing the mutual economic relations again and is raising the question whether there is a hope for normalization of trade relations in the nearest future between the Baltic

Received: September, 2017 1st Revision: December, 2017

Accepted: January, 2018

$10.14254 / 2071$ $8330.2018 / 11-1 / 1$ countries and Russia. Thus, the article focuses on the trade dynamics between the Baltic countries and Russia over the period 2004-2016 and analyses the main factors that have influenced this trade dynamics. The article will also debate the outlook for trade relations to be normal again in the light of the sanctioning war between Russia and the EU and its allies.

Keywords: Baltic States, Russia, sanctions, conditionality, interdependence.

JEL Classification: F1, F5, P4

\section{INTRODUCTION}

Small open economies tend to be highly vulnerable to external uncontrollable shocks. Since small economies are highly dependent on external trade, they are also exposed to developments in the global arena, over which they have little if any influence (World Bank, 2000). High dependency on one or two external markets makes them particularly vulnerable to the economic turbulences of their trade partners, since these turbulences will be automatically transferred to their own growth prospects. 
This also applies to the Baltic countries, since they have often faced serious difficulties related to their economic openness after sovereignty restoration at the beginning of the 1990s. Next to the global economic developments, on several occasions Russia's actions have represented a serious challenge for Estonia, Latvia and Lithuania. Mutual economic relations of all three these countries with Russia have been particularly tense at the beginning of the 1990s, in 1995-1997, in 2008-2009 and then from 2012 on, when Russia has put economic, political, propagandist and administrative pressure on the Baltic countries.

However, during the past 20 years entrepreneurs of the Baltic countries have been still interested in developing trade relations with Russia despite constant setbacks. This phenomenon has also motivated the authors of the current research to investigate whether specific factors have influenced the economic relations between the Baltic countries and Russia particularly over the period 2004-2016. Furthermore, this analysis also contributes to the discussion on the outlook for normalisation of trade relations between the Baltic countries and Russia in the light of the "sanctioning war" that has erupted between the Western countries and Russia during the ongoing Russian-Ukrainian conflict. The potential resurgence of the factors that have contributed to the deepening of mutual trade relations over the period 2004-2016 will be estimated based on the assumption that mutual sanctions will be eliminated at a certain moment of time in the future. The questions under what conditions and when exactly it could happen will be hereby left aside. Methodologically, the article uses descriptive, analytical and comparative methods. Discussion on the future prospects of mutual trade relations is to a large extent hypothetical, reflecting solely the views of the authors.

\section{THE BUST AND THE BOOM: TRADE RELATIONS BETWEEN RUSSIA AND THE BALTIC COUNTRIES IN 2004-2016}

Over the past decade, the trade relations between Russia and the Baltic countries have experienced turbulent times. Due to close economic ties inherited from the Soviet Union, Russia was the first trading partner for all three Baltic countries shortly after Estonia, Latvia and Lithuania have restored their sovereignty in the beginning of the 1990s. In 1991, 90\% of the total imports of Estonia, Latvia and Lithuania originated from Russia (Oldberg, 2003). However, in the following years trade diversion from Russia to the EU member states and the associated countries has taken place and in 1994, Russia's share in the total imports of the Baltic countries was only $21 \%$ for Estonia, $29 \%$ for Latvia and $46 \%$ for Lithuania (Ibid.). The trade diversion could be explained by the strengthening of economic relations between the Baltic countries and the Western world simultaneously to the progress made by the Baltic countries towards EU integration. At the same time, Russia's high tariffs on the imports from the Baltic countries and constant threats to impose sanctions against its neighbours have also played an important role. For these reasons, the Baltic countries have to a greater or lesser extent further reduced the dependency on Russia's market through the 1990s. Shortly before the accession of the Baltic countries to the EU in 2004, Russia's share in the total exports and imports of Estonia was about 6-9\% and of Latvia about 8\%. Russia's share has remained relatively high in the trade exchange of Lithuania, constituting about $28 \%$ in the total imports and about $10 \%$ of the total exports of Lithuania in 2004-2005 (author's calculations based on Compiled statistics... 2015). To sum up, trade diversion from Russia to the other countries has taken place in Estonia, Latvia and Lithuania during the period 1991-2004 due to the political and economic reorientation of the Baltic countries and Russia's restrictive trade policy towards its Baltic neighbours.

At first sight paradoxically, trade between the Baltic countries and Russia has increased significantly after the EU Eastern Enlargement in 2004 until 2006/2007 (Fig. 1). 


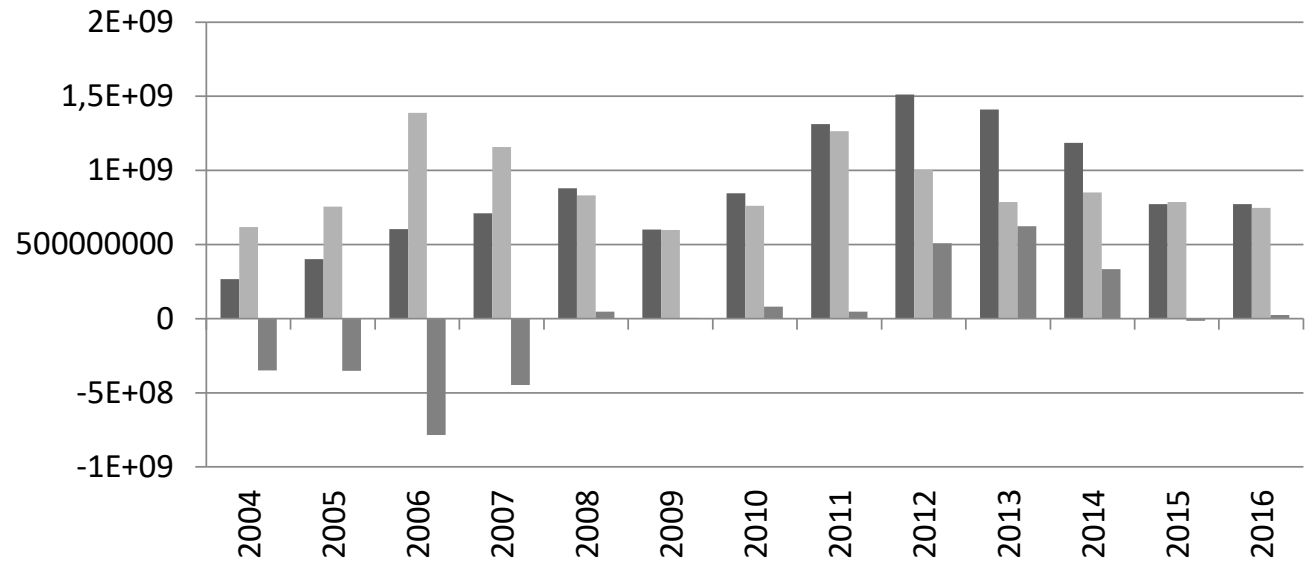

Exports to Russia: Estonia (euros) Imports from Russia: Estonia (euros)

Balance: Estonia (euros)

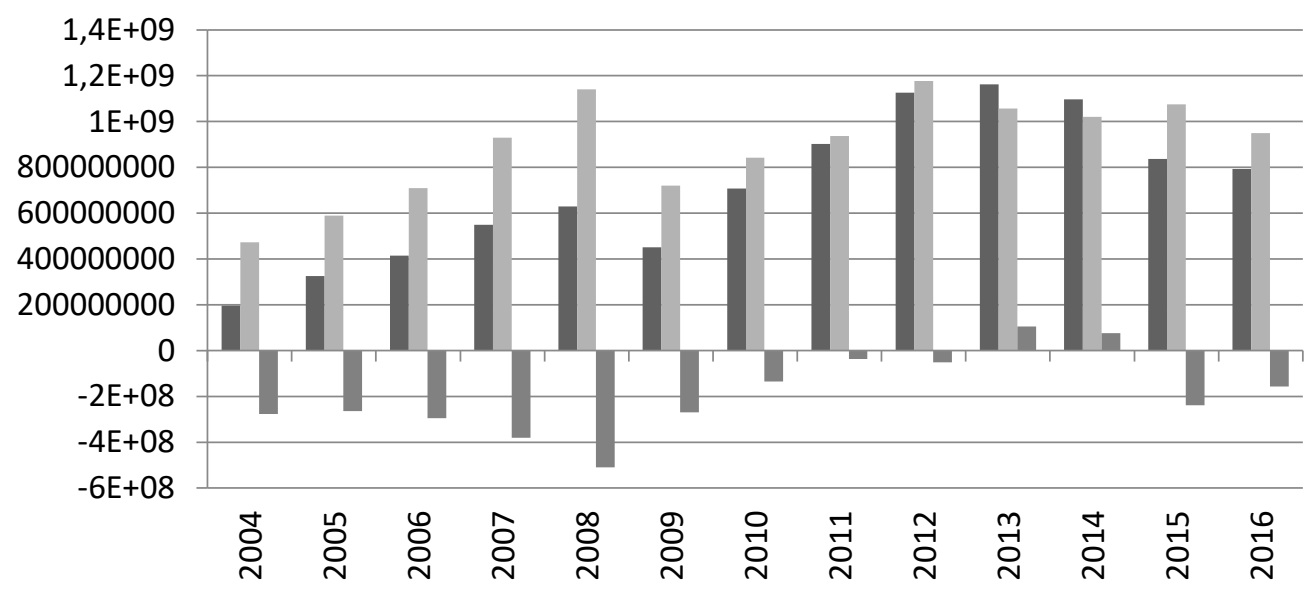

Exports to Russia: Latvia (euros) Imports from Russia: Latvia (euros)

Balance: Latvia (euros)

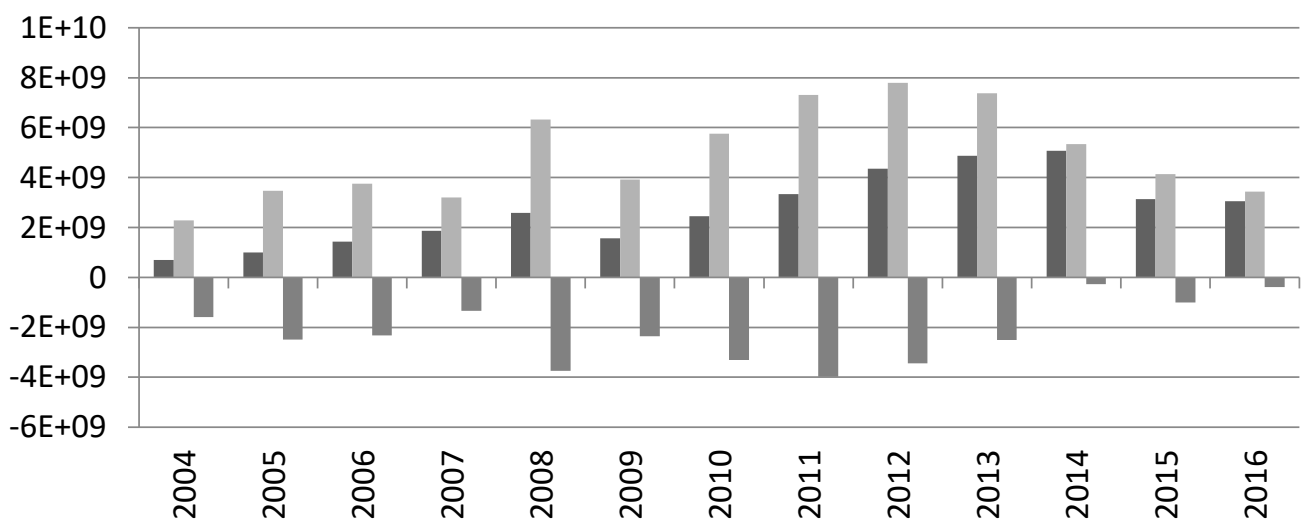

Exports to Russia: Lithuania (euros) Imports from Russia: Lithuania (euros)

Balance: Lithuania (euros)

Figure 1. Trade between Russia and Estonia, Latvia and Lithuania in 2004-2016

Source: Complied statistics..., 2017 
On the one hand, it could be associated with the extensive trade relations between the Baltic countries and the member states of the EU already before the enlargement of the EU in 2004. On the other hand, European integration also provided a more stable basis for the development of further contacts between the Baltic countries and Russia in the framework of the EU foreign policy, the EU Eastern Partnership and the EU external trade policy. In view of this it could be argued that the European integration has also motivated the entrepreneurs of the Baltic countries to develop more extensive economic contacts with Russia, mostly due to the abolition of double tariffs from Russian side which has particularly increased the exports of the Baltic countries to Russia. In a more general sense the EU accession has also provided a firm foundation for the development of cooperation and trade exchange with Russia.

However, one should not forget that the eastern enlargement of the EU has also deepened some of the earlier tensions between the neighbouring countries related, for example, to the transit through Lithuania, to the EU-Russia Partnership and Cooperation Agreement established in 1997 and to the energy dependency of the Baltic countries on Russia (DeBardeleben, 2009).

The "boom" in 2004-2006/2007 was followed by the "bust" period in mutual trade relations during the global economic crisis in 2008-2009. As the authors see it, next to the impact of the global economic crisis also Russia's trade restrictions and import bans to the products from the Baltic countries should be taken into account here. For example, in 2009 Russia imposed stricter border controls in Russia's border with the Baltic countries (Mauricas, 2015a). However, also the impact of both Russia's attempts to politically destabilize the Baltic countries from 2007 on and the violent actions in Georgia in 2008 should be taken into account, when discussing the reasons for the setback in trade relations in 2008-2009. In detail, the authors refer to the so-called Estonian Bronze Soldier monument crisis and the call by the Russian Federation Council to cease diplomatic relations with Estonia in April 2007 accompanied with large-scale cyber-attacks against Estonian state institutions, the blockade of the Estonian embassy in Moscow in May 2007 by the Russian youth movements, the boycott calls by Russian officials against Estonian products in Summer 2007, the blocking of the truck traffic at the main bridge into Estonia and the cut-off of the delivery of oil, coal and petroleum products to Estonia in May 2007 (Roth, 2009). Although it has been argued that political tensions in Estonia in 2007 have led to the reduction of transit but not the Estonia's exports to Russia (Kitsing 2015, 1), the authors of the current article believe that Russia's actions in 2007 have particularly increased the cautiousness in Estonia regarding developing economic contacts with Russia and the economic and political risks associated with Russia's ambitions to increase its sphere of influence in the former Soviet Union republics. This cautiousness is also reflected in trade relations between Estonia and Russia which have declined remarkably after events in Spring 2007, based on the monthly data.

After turbulent years in 2008-2009, trade between the Baltic countries and Russia has intensified again in 2010-2012. On the one hand, it is related to the economic recovery of the region after the global economic crisis. On the other hand, to some extent the increase in imports from Russia could be again associated with high oil prices.

It has been argued that Russia's accession to the World Trade Organisation (WTO) in August 2012 has improved opportunities for European exporters to access the Russian market, since subsidies in the Russian agricultural sector were reduced and Russian import duties on agricultural and industrial products were decreased as a result of the accession procedure (Ratso, 2015; The Employer's House, 2012). Thus, one might have expected that the trade between Russia and the Baltic countries would have been intensified also after 2012. However, this has not been visible in the trade dynamics between the Baltic countries and Russia from 2012 on. On the contrary, Russia has used several measures to restrict mutual trade relations. For example, in 2012 Russia banned imports of live animals from Estonia and introduced partial sanctions on Estonian fishery and dairy products (Statistics..., 2014) and in the end of 2013 banned all dairy imports 
from Lithuania (Mauricas, 2015a). Given both the historical background and the previous experiences from 2007-2009, the authors believe that this has even further decreased the incentives of the Baltic entrepreneurs to develop trade relations with Russia.

To conclude, Russia is important trade partner mostly for Lithuania. At its peak over the past decade, Lithuania's imports from Russia accounted for 30\% of total imports, and exports to Russia accounted for $20 \%$ of country's total exports (see Fig. 2). Russia's share in foreign trade of Estonia and Latvia is lower, varying from 6 to $11 \%$ of total foreign trade. In this light it would be reasonable to assume that Lithuania will be most vulnerable among the Baltic countries to the political and economic instability stemming from Russia. Trade balance with Russia has been negative over the entire 10-years period in Lithuania and during most of the period in Latvia, as could be seen from Fig. 1. Remarkably, although in Estonia the total external trade has been in constant deficit during the whole period, trade with Russia is in surplus already since 2008 (see Statistical Office..., 2015). The country's trade surplus with Russia is mainly associated with the growth in the exports of machinery and electrical equipment and products of chemical or allied industries and with the cyclical developments in the imports of mineral products and fuels from Russia.
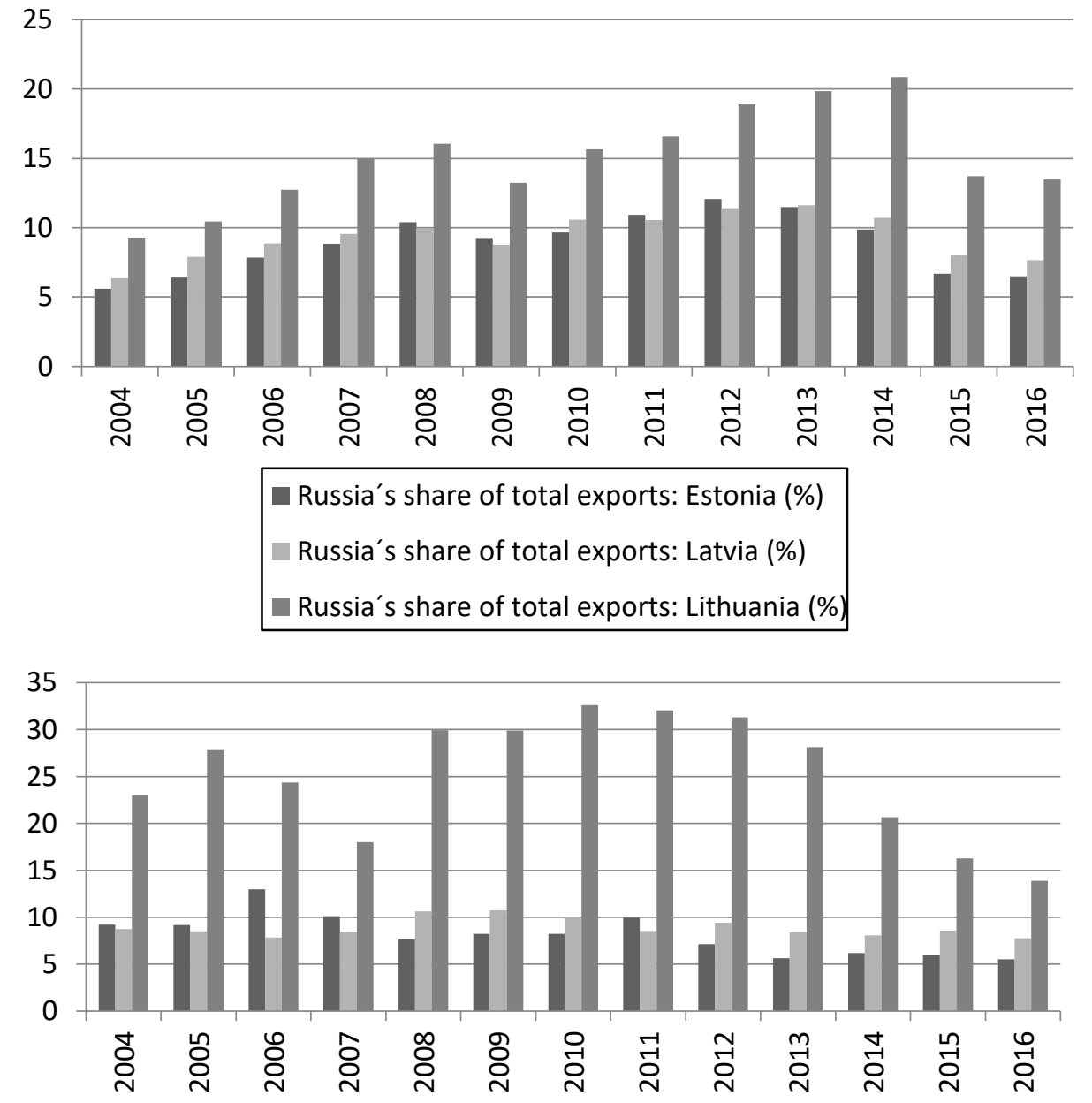

$\square$ Russia's share of total imports: Estonia (\%)
Russia's share of total imports: Latvia (\%)
Russia's share of total imports: Lithuania (\%)

Figure 2. Russia's share in total exports and imports of the Baltic countries over in 2004-2016 Source: Compiled statistics..., 2017 


\section{THE "SANCTIONING WAR" IN 2014-2016: IMPLICATIONS FOR THE BALTIC COUNTRIES}

Political tensions between Russia and Ukraine in 2013 have culminated in the violation of territorial integrity of Ukraine in March 2014 and military conflicts in the eastern part of Ukraine forced by Russia from 2014 on. To resolve the conflict, in March 2014 the EU and its partners have decided to impose travel bans and asset freezes against Russian and Ukrainian officials involved in Russia's annexation of Crimea and to cancel the EU-Russia summit. The scope of individuals and entities subject to the Western sanctions has been gradually widened in April, May and July 2014. Russia responded with retaliatory sanctions against high-ranked officials of the EU, USA and Canada in March 2014. In July 2014, the EU announced sectorspecific sanctions against the Russian military industry and financial and energy sector, which restricted country's access to international capital markets and placed an embargo on trade of arms and sector-related technologies. As a countermeasure, on 6th August 2014, Russian President Vladimir Putin signed a decree "On the use of specific economic measures", which mandated an effective embargo for a one-year period on imports of most of the agricultural products whose country of origin had either adopted the decision on introduction of economic sanctions in respect of Russian legal and (or) physical entities, or joined same. The Russian government ordinance was adopted and published with immediate effect, which specified the banned items as well as the countries of provenance: the member states of the European Union, but also the United States, Norway, Canada and Australia, including a ban on fruit, vegetables, meat, fish, milk and dairy imports .

In September 2014, the leaders of the EU and the US have agreed on additional sanctions, forbidding state-controlled Russian oil and defence companies from raising money in European capital markets and cutting off foreign investments. Further additions to the list of persons, organizations and companies under sanctions have been made in November 2014. In response to this, Russia continued to restrict trade with the West. In June 2015, the EU Council extended economic sanctions against Russia until the end of January 2016. Russia responded with additional sanctions and with additional legal and economic measures to integrate Crimea into Russia.

In July 2015, the leaders of the European Union have agreed on additional sector-specific sanctions against Russia. As a result, following restrictions have been in force from the EU side since 19 July 2015:

1. EU nationals and companies may no longer buy or sell new bonds, equity or similar financial instruments issued by five major state-owned Russian banks, three major Russia energy companies and three major Russian defence companies.

2. Services related to the issuing of such financial instruments, e.g. brokering, are also prohibited. EU nationals and companies may not provide loans to five major Russian state-owned banks.

3. Embargo on the import and export of arms and related material from/to Russia. Prohibition on exports of dual use goods and technology for military use to Russian military end-users . Export of dual use goods to nine mixed defence companies is also banned.

Exports of certain energy-related equipment and technology to Russia were subject to prior authorisation by competent authorities of Member States. Export licenses were and are denied if products are destined for deep water oil exploration and production, arctic oil exploration or production and shale oil projects in Russia. On 10 March 2016, the restrictive measures against 146 people and 37 companies in Russia were extended by six months by the EU (Council of..., 2016). On 13 March 2017, the Council prolonged the restrictive measures over actions undermining or threatening the territorial integrity, sovereignty and independence of Ukraine for a further six months, until 15 September 2017. Despite Russian efforts to lift the sanctions the Council decided on 21st of December 2017 to prolong the sanctions against Russia until 31. July 2018. The measures consist of asset freezes and a travel bans. 
How much have the Russian sanctions against the EU member states affected the economies of the Baltic countries and what are the prospects for the "normalization" of mutual economic relations in the future? In general, the impact of the Russian sanctions on the growth prospects for the EU has been estimated to be rather limited. According to the estimation of the European Commission, the negative effect is caused by the lower demand for imports from European countries and from the Russia's countersanctions and the "sanctioning war" have decreased the EU's economic growth by 0.3 to 0.4 percentage points in 2014 and 2015. The effect of asset freezes and visa bans were considered as rather secondary (Bond et al., 2015). Vanden Houte (2014) has estimated that the European economy would have been grown by one $\%$ additionally in 2015, if the sanctions have not been imposed. The direct impact of sanctions would be relatively minuscule, as the GDP growth would be lower by about half of a tenth of a percentage point. Havlik (2014) states that in terms of trade exposure, machinery, transport equipment and electrical equipment are the most important export branches exposed to Russia in the EU, whereas food products which are banned by Russia do not feature prominently among the EU exports to Russia, but are extremely important to some EU countries, such as the Baltic States (Veebel \& Markus, 2016).

Although the impact of the Russian sanctions on the growth of the EU and the euro zone has been estimated as rather limited several EU countries have nevertheless announced that they faced serious difficulties due to the Russian sanctions and asked for measures to compensate it (Oja, 2015). Compared with other EU member states, the Baltic countries are mostly affected by the Russian sanctions according to the estimations. For example, Mauricas (2015a) has stated that an overall direct effect of Russian sanctions on the economic growth in the whole Baltic region amounts to $0.6 \%$ of GDP, but, as expected, Lithuania has suffered the most from the "sanctioning war". The direct effect of Russian sanctions on economic growth in 2014 amounted to $0.81 \%$ of GDP in Lithuania, $0.46 \%$ in Estonia and $0.44 \%$ in Latvia.

Figure 3 indicates that the Russian sanctions have mostly affected exporters in Baltic States and in all three countries the major slump in exports has taken place in the first quarter of 2015. The fall in exports has been particularly sharp regarding the exports of dairy products. According to Mauricas (2015b), the overall export of dairy products fell by $23 \%$ in Lithuania, 32\% in Latvia and 36\% in Estonia from August 2014 to April 2015 due to the sanctions. However, the decline in exports to Russia has been partially compensated by the growth in exports to the other regions (Oja, 2015; Kitsing, 2015).

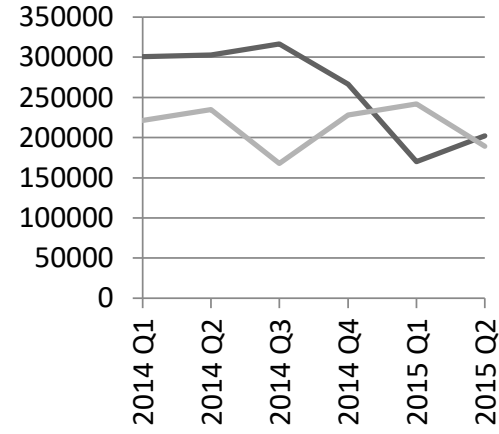

(a) Estonia

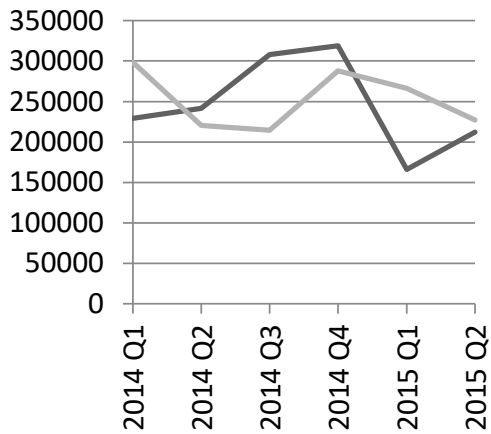

(b) Latvia

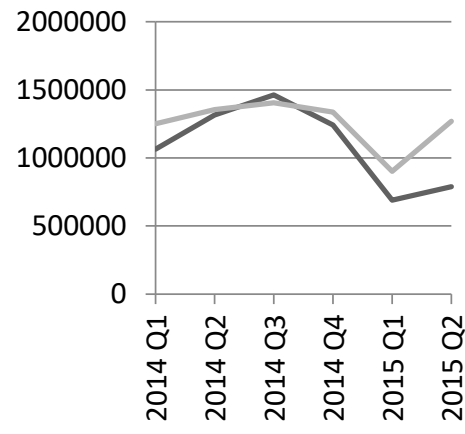

(c) Lithuania

Figure 3. Trade between Russia and Baltic States in 2004Q1-2015Q2 (dark line denotes the dynamics of exports and light line denotes the dynamics of imports)

Source: Compiled statistics..., 2017.

To sum up, Russian sanctions have seriously damaged some economic sectors in the Baltic countries, such as food and agricultural sector, and have mostly affected exporters in Lithuania, Latvia and Estonia. 
The overall effect of sanctions on the economies of the Baltic countries has not been remarkable, ranging from 0.4 to $0.8 \%$ of the country's GDP. However, small open economies that have high shares of foreign trade to the GDP are very vulnerable to the risks related to the turbulences in foreign markets. Thus, next to the trade dynamics between the Baltic countries and Russia, also secondary effects (i.e. the impact of sanctions on the Finnish, German, Polish and the Dutch economy) should be taken into account in the long run when discussing the impact of Russian sanctions on the economies of the Baltic countries.

\section{PROSPECTS FOR THE "NORMALIZATION" OF MUTUAL TRADE RELATIONS IN THE FUTURE?}

In the light of the ongoing "sanctioning war" between the EU and Russia, it is appropriate to ask what would be the outlook for the "normalisation" of trade relations between the Baltic countries and Russia in the future assuming the mutual sanctions will be eliminated at a certain moment in time. This topic has been only marginally touched both in the academic literature and the political debates by now. For example, Zvaigzene (2015) has argued that "in the near future Latvian producers will not be either anxious or motivated on trade with Russia, rather relying on other, more stable markets. This means that, even if the sanctions end, most producers would bide their time before returning to the Russian market. Besides, some Russian companies have already invested in entering other markets worldwide". Ratso $(2015,1)$ has stressed that the long-term strategy of the Estonian entrepreneurs should rely more on diversifying risks and that the local processors should focus on the products with higher added value, since it is easier to find other markets and to ask better price for such products. Thus, despite the proximity of the Russian market, particularly Estonian agricultural producers should focus on the other markets rather than Russia which is politically sensitive and insecure (Ibid.).

The authors of the current article share the view that the "normalisation" of the trade relations between the Baltic countries and Russia in the nearest future is rather unlikely. Trade relations between the neighbours are directly linked to the sanctions which are currently valid until 31. July $2018^{1}$. Under these circumstances, it would be irrational to expect that particularly Russia's import from the Baltic countries would increase, at least, in the short term. On a wider scale, also the "stigmatisation" of Russia in the international arena speaks against the deepening of trade relations. Finally, also the impact of the instability stemming from Russia's earlier attempts to use trade policy as a tool to put pressure on its neighbour countries as well as country's geopolitical ambitions in the region, jailing of the entrepreneurs and oligarchs in Russia and demonstrative destruction of food products originated from the Western countries should not be underestimated.

At the same time, the recent past has shown that trade relations between Russia and the Baltic countries have been in decline on more than one occasion over the past 10-20 years, but have recovered after some time has passed. This raises the question whether the entrepreneurs of the Baltic countries could be interested in trading with Russia after lifting the sanctions in the future. Based on the previous experiences, the European integration has motivated the entrepreneurs of the Baltic countries to deepen economic contacts with Russia in 2004-2007/2008, whereas sanctions and other restrictive measures imposed by Russia have hampered both mutual economic relations and the prospects for the normalisation of economic contacts.

1 Council of European Union. (2017). Press release, Russia: EU prolongs economic sanctions by six months http://www.consilium.europa.eu/en/press/press-releases/2017/12/21/russia-eu-prolongs-economic-sanctions-by-six-months/ 
The recovery of trade exchange between the Baltic countries and Russia could be possible if: a) the cooperation between the EU and Russia will reach the stage that brings significant benefits for the producers of the Baltic countries, or b) the risks related to the Russia's erratic behaviour on the international stage will decrease significantly. The first potentially relates to the outlook for the strategic partnership between the EU and Russia. Today, mutual relations rely on the Partnership and Cooperation Agreement that is in force since 1997. The negotiations on the new agreement in the form of the strategic partnership were launched in 2008, however, in the light of the Russia's actions in Crimea and in the eastern part of Ukraine the talks on the new cooperation agreement have been suspended (Veebel, 2017). In this sense, the new cooperation agreement between the EU and Russia may present an opportunity for the Baltic countries to create favourable conditions in their trade relations, assuming that at certain point in time the negotiations on the new cooperation agreement between the EU and Russia will continue. The second would be associated with the change of political regime in Russia. It could be argued that the hidden agenda of the Western sanctions against Russia has been to cause the regime change in Russia without destroying the country economically. Assuming that regime change is indicated solely by a growing dissatisfaction among Russian citizens, the regime change is rather unlikely in the near future because both the strong opposition wing and the political alternatives are missing in Russia.

To sum up, also the comparison of the factors that have contributed to the deepening of mutual trade relations over the period 2004-2016 with the current circumstance and political communication of both side indicate that the normalisation of trade relations between the Baltic countries and Russia is rather unlikely in the nearest future even if mutual sanctions will be eliminated. In 2018, the situation offers rather few rational reasons for the "normalization" of trade relations between the Baltic countries and Russia in the nearest future. First there is lack of motivation from Russia's side as recent economic developments in Russia indicate the country is able to survive and recover under veritably challenging economic conditions. Even when sanctions are prolonged both by the European Union and the US, the economic situation in Russia is slowly stabilizing after the turbulence in 2015-2016: the economy has contracted at a slower pace from the fourth quarter of 2015 on, the inflation rate has dropped from 15-16 percent in the second half of 2015 to 2,5 percent in the end of 2017 and the exchange rate of the Russian ruble has strengthened from spring $2016 \mathrm{on}^{2}$. Second there is also lack of motivation from Baltic side: Russia's constant attempts to use external trade policy as an instrument of pressure and country's aggressive behaviour on the international stage increases the likelihood that the Baltic countries would rather avoid to deepen the trade relations with Russia in the nearest future. The most likely scenario today sees the current "status quo" as maintained - at least in the mid-term period or as long the EU sanctions against Russia are in force.

In principle, the motivation for the Estonian, Latvian and Lithuanian enterprises to deepen trade relations with Russia could be also related to the size and the proximity of the Russian market. Russia's long term growth prospects are limited by the demographic situation and constraints on competition and private investment (see, e.g. Future Security..., 2015). However, under favourable economic conditions, the Russian market might have considerable potential. This is confirmed by the comparison of data from the latest economic recession in the Baltic countries, in Russia and in the EU (Figure 4). On the average basis, Russia has faced more serious economic recession than the EU on the average, but despite its structural weaknesses, the Russian economy seems to be recovered from the recession in 2008-2009 faster than the $\mathrm{EU}$ and the Baltic countries, as indicated in Figure 4. The recovery of Russian economy from recession in

2 The Statistics Portal (2017). Russia: Growth of the real gross domestic product (GDP) 2014-2016, http://www.statista.com/statistics/276951/gross-domestic-product-gdp-growth-rate-in-russia-by-quarter/ 
2014-2016 caused by combined reasons is still in progress and Russian GDP has not been able to reach the previous peak from year 2013.

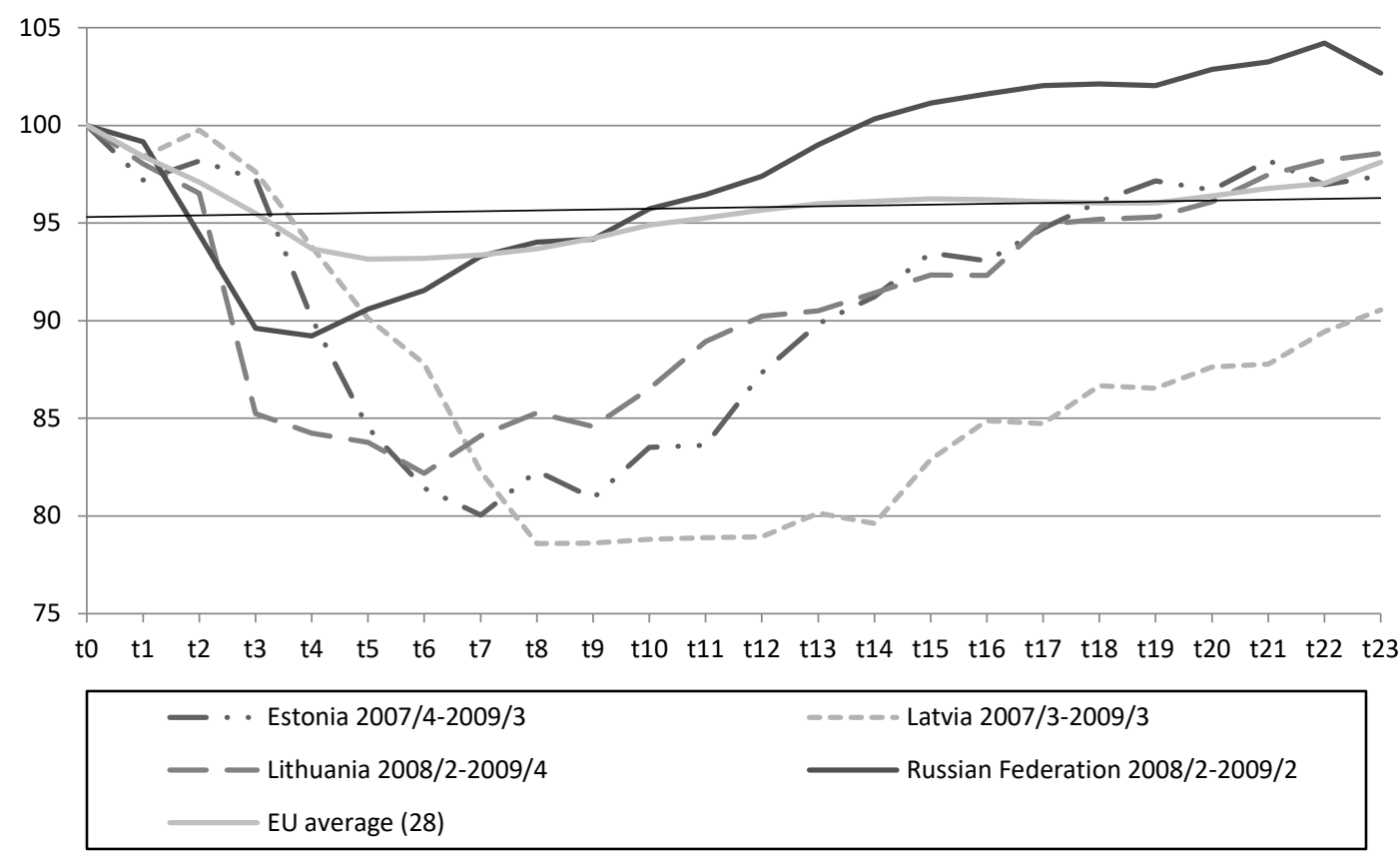

Figure 4. The real GDP growth compared to the economic peak in Baltic States, Russia and in the EU (on the average basis); quarterly data

Note: The peak of the economic cycle is noted as $t 0$. The period from $t 1$ to $t 23$ refers to the 6 -years period after the economic peak. In Estonia, the economic peaks was in the $4^{\text {th }}$ quarter of 2007, in Latvia in the $3^{\text {rd }}$ quarter of 2007, in Lithuania and in Russia in the $2^{\text {nd }}$ quarter of 2008.

Source: author's calculations based on IFS (2015).

Additionally, the motives of the Baltic countries to deepen economic relations with Russia could be associated with the aim to enhance the security and reduce the risk of regional conflict (Veebel and Markus 2015, 169), inspired by the Western motives to enhance the cooperation with Russia in the 1990s and to conclude the Partnership and Cooperation Agreement with Russia in 1997.

\section{CONCLUSION}

The present article focused on the factors that have influenced the trade relations between the Baltic countries and Russia over the past decade and on this basis, discussed the future prospects for the normalisation of trade relations, assuming that current mutual sanctions will be eliminated at a certain moment in time in the future. The research has been motivated by the phenomenon that in past 20 years the entrepreneurs of the Baltic countries have been interested in developing trade relations with Russia despite constant setbacks.

To sum up, "boom" and "bust" periods have occurred in trade relations between the Baltic countries and Russia over the past decade. The trade has grown in 2004-2006/2007 and 2010-2012, mainly due to the abolition of double tariffs from Russian side in 2004, and the high level of oil prices in 2007-2008 and in 2012. Also more stable basis for further contacts between the Baltic countries and Russia has been established in the framework of the EU foreign policy, the EU Eastern Partnership and the EU external trade policy after the eastern enlargement of the EU. The "bust" period occurred during the global economic 
crisis in 2008-2009 and from 2012 on as a result of the "sanctioning war" between Russia and the Western world.

In 2018, the situation offers rather few rational reasons for the "normalization" of trade relations between the Baltic countries and Russia in the nearest future. First there is lack of motivation from Russia's side as recent economic developments in Russia indicate the country is able to survive and recover under veritably challenging economic conditions. Second there is also lack of motivation from Baltic side: Russia's constant attempts to use external trade policy as an instrument of pressure and country's aggressive behaviour on the international stage increases the likelihood that the Baltic countries would rather avoid to deepen the trade relations with Russia in the nearest future. The most likely scenario today sees the current "status quo" as maintained - at least in the mid-term period or as long the EU sanctions against Russia are in force.

Next to that the authors argue that in theory, the recovery of trade exchange between the Baltic countries and Russia could be possible if: a) the cooperation between the EU and Russia will reach the stage that brings significant benefits for the producers of the Baltic countries, or b) the risks related to the Russia's erratic behaviour on the international stage will decrease significantly. What could be really challenging for the Baltic countries is the more fundamental shift in the export structure. More precisely, the re-orientation of the Baltic entrepreneurs from Russian market to other markets should go hand in hand with the concentration on products with higher added value. The importance of the diversification of risks has been stressed also by several experts. In a longer term, this would enable the Baltic countries to limit the losses stemming from the trade relations with Russia.

\section{REFERENCES}

Bond, I., Odendahl, C. \& Rankin, J. (2015). Frozen: the politics and economics of sanctions against Russia. March 2015. Retrieved from http://www.cer.org.uk/sites/default/files/publications/attachments/pdf/2015/frozen sanctions10787.pdf

Complied statistics. (2017). The foreign trade data from the following sources. Retrieved from http://pub.stat.ee/pxweb.2001/Dialog/Saveshow.asp

http://data.csb.gov.lv/pxweb/en/atirdz/atirdz ikgad atirdz/AT0020 euro.px/table/tableViewLayout2/?rx $\mathrm{id}=\mathrm{a} 79839 \mathrm{fe}-11 \mathrm{ba}-4 \mathrm{ecd}-8 \mathrm{cc} 3-4035692 \mathrm{c} 5 \mathrm{fc} 8$ and https://osp.stat.gov.lt/en GB/uzsienio-prekyba1

Council of the European Union. (2014). Council Regulation (EU) No 1290/2014 (OJ L 349, 5 December 2014.

Council of the European Union. (2014). Council Regulation (EU) No 960/2014 (OJ L 271/3, 12 September 2014).

Council of the European Union. (2014). Council Regulation (EU) No 833/2014 (OJ L 229, 31 July 2014).

Council of the European Union. (2014). Council Regulation (EU) 1290/2014 (OJ L 349, 5 December 2014).

Council of the European Union. (2014). Council Regulation (EU) 1290/2014_(OJ L 349, 5 December 2014).

Council of European Union. (2017). Press release Russia: EU prolongs economic sanctions by six months http://www.consilium.europa.eu/en/press/press-releases/2017/12/21/russia-eu-prolongs-economicsanctions-by-six-months/

DeBardeleben, J. (2009). The End of the Cold War, EU Enlargement and the EU-Russian Relationship. London School of Economics. Retrieved from http://www.lse.ac.uk/IDEAS/publications/reports/pdf/SR018/DeBardeleben.pdf

European Union External Actions: EU relations with Russia. (2016). Retrieved from http://eeas.europa.eu/russia/about/index en.htm

Future Security Challenges in the Baltic Sea Region: A study for the Swedish Armed Forces by the Development, Concepts and Doctrine Centre. (November, 2015). Retrieved from https://www.gov.uk/government/uploads/system/uploads/attachment data/file/494595/20151201-

Baltic sea regional security.pdf

Government of Russia. (2014a). О мерах по реализации Указа Президента России «О применении отдельных специальных экономических мер в целях обеспечения безопасности Российской Федерации». Retrieved from http://government.ru/docs/14195/

Government of Russia. (2014b). Постановление Правительства Российской Федерации от 21.08.2014 г. № 835, О дополнительных мерах по регулированию импорта мяса крупного рогатого скота и мяса домашней птицы. Retrieved August 21, 2014 from http://government.ru/docs/all/92613/ 
Havlik, P. (2014). Economic Consequences of the Ukraine conflict. WIIW Policy Notes and Reports, November 2014. Retrieved from http://wiiw.ac.at/economic-consequences-of-the-ukraine-conflict-dlp-3427.pdf

IFS (International Financial Statistics). (2015). Data on the Real GDP growth. Retrieved from http://elibrarydata.imf.org $/$ finddatareports.aspx?d $=33061 \&$ e $=169393$

Kitsing, M. (2015). The Boomerang Effect of Russian Trade Policy Measures Against Estonia. Society for the Advancement of $\begin{array}{llllll}\text { Socio-Economics } & \text { (SASE), } & 33 & \text { July } & 2015 . & \text { Retrieved }\end{array}$ https://sase.confex.com/sase/2015am/webprogram/Paper3159.html

Mauricas, Z. (2015a). The effect of Russian economic sanctions on Baltic States. Overview of the Nordea Bank AB. Available: https://nexus.nordea.com/research/attachment/17231

Mauricas, Z. (2015b). Baltic: Yes, We Can!... Live Without Russia. Published by the Nordea Bank AB on 11 August 2015. Retrieved from https://nexus.nordea.com/\#/article/21499

Oja, K. (2015). No milk for the Bear, the impact to the Baltic states of Russia's counter sanctions. Baltic Journal of Economics, 15(1), 38-49.

Oldberg, I. (2003). Russia's Baltic policy in an era of EU integration. In Herd, G.P., and Moroney, J. D.P. Security Dynamics in the former soviet block. RoutledgeCurson.

Ratso, S. (2015). EU-Russia Trade Relations in Light of Sanctions and Russia's Import Measures. Diplomaatia, March 2015. Retrieved from http://www.diplomaatia.ee/en/article/eu-russian-trade-relations-in-light-of-sanctionsand-russias-import-measures/

Roth, M. (2009). Bilateral Disputes between EU Member States and Russia. CEPS Working Document No. 319/August 2009.

Statistics Estonia. (2014). Eesti eksport Venemaale on 2014. aasta esimesel poolaastal vähenenud. Retrieved from https://statistikaamet.wordpress.com/2014/09/04/eesti-eksport-venemaale-on-2014-aasta-esimeselpoolaastal-vahenenud/(in Estonian)

The Employer's House. (2012). Venemaa pääs WTOsse and Eesti ekspordile hoogu (in Estonian). Retrieved from http://www.employers.ee/ru/vaatenurk/12927-venemaa-paeaes-wtosse-annab-eesti-ekspordile-hoogu

The Statistics Portal. (2017). Russia: Growth of the real gross domestic product (GDP) 2014-2016. Retrieved from http://www.statista.com/statistics/276951/gross-domestic-product-gdp-growth-rate-in-russia-by-quarter/

The World Bank. (2000). Small States: Meeting Challenges in the Global Economy. Report of the Commonwealth Secretariat / World Bank Joint Task Force on Small States, April 2000. Retrieved from http://www.cpahq.org/cpahq/cpadocs/meetingchallengeinglobaleconomyl.pdf

Vanden Houte, P. (2014). Referred in Euro zone economy grinds to halt even before Russia sanctions bite. Reuters, 15 August 2015. Retrieved from http://uk.reuters.com/article/2014/08/15/uk-eurozone-economyidUKKBNOGE0IG20140815

Veebel, V., \& Markus, R. (2015). Lessons from the EU-Russia sanctions 2014-2015. Baltic Journal of Law \& Politics, 8(1), 165-194.

Veebel, V., \& Markus, R. (2016). At the dawn of a new era of sanctions: Russian-Ukrainian crisis and sanctions. Orbis, 60(1), 128-139.

Veebel, V. \& Markus, R. (2016). Will sanctions against Russia be successful: will Russia fall before Ukraine?. Journal of Security and Sustainability Issues, 5(4)

Veebel, V. (2017). Russia's neo-imperial dependence model: Experiences of former Soviet republics. Romanian Journal of Political Science, 17(1).

Zvaigzene, A. (2015). EU sanctions against Russia renewed: pros and cons for business and Baltics economy. The Baltic Course, 28 December 2015. Available: http://www.baltic-course.com/eng/analytics/?doc=114794 